\title{
Challenges of the Industrial Revolution 4.0 on the Education of the Poor Case Study: Disparities Education on Length of Schools in Sumatera
}

\author{
Eko Wahyu Nugrahadi ${ }^{1}$, Joko Suharianto ${ }^{2}$, Anhar Fauzan Priyono ${ }^{3}$ \\ ${ }^{1,2)}$ Faculty of Economics, Universitas Negeri Medan, Indonesia \\ ${ }^{3)}$ Faculty of Economics and Business, Padjajaran University, Indonesia \\ *ewahyunugrahadi@yahoo.com
}

\begin{abstract}
Inequality in Indonesia shows this quite moderate. This inequality is not just talking about income inequality, but also occurred in the inequality of access to education. Access to education in the poor be interesting to do the analysis. The purpose of this research study analyzes the inequality in access to education to the poor. The model used is the inequality of econometric panel data models for the provinces in Indonesia and specify on the island of Sumatra. The results of data processing showed inequality in access to education is influenced by income per capita, local government spending on education, income inequality and aged between 15-65 years. Per capita income of Lampung province has the most powerful influence on educational inequality decrease the average length of schooling of the population is poor. Government spending in education, the increase in per capita income, a decrease in income inequality into a powerful instrument for pressing educational inequality average length of schooling of the population is poor. If this effort is congested, then the threat of the low quality of human resources certainly facing the nation and much of the produce of labor which is not relevant to the development of technology or drowned by this disruption era.
\end{abstract}

Keywords: Education, Inequality, Poor, Sumatera

\section{Introduction}

Education is fundamental to establish broader human capabilities that are at the core of the meaning of development. The fundamental objective of development is education and human health [1]. Education has an important role in the development because education is an investment in improving human resources, strengthening of physical capital, and the ability to customize the techniques applied to industrial machines [2]. The quality of human capital depends on education. The higher the level of education, the quality or productivity of the man expected to be higher. Educational attainment as a form of measuring the quality of human capital cannot be achieved in the same degree for all societies. Higher education and a healthy life require a lot of high costs so that not all people can get education to the fullest.

The challenge of increasing the quality of education is increasingly severe with the increasing development of technology and information. 4.0 Industrial Revolution became a marker development phase of human life is more involving technology in all facets of life. The Industrial Revolution 4.0 fundamentally results in changes in the way people think, live and relate to one another. This era will get disruption various human activities in various fields, not only in technology, but also in other areas such as economic, social, political, and of course, that also undergone major changes in the field of education. Problems of quality 
education today is certainly a threat to generation Z. Referring to the concept proposed by Hurlock [3] 13-18 year age range included in the category of adolescence, where teenagers at this time include the category Generation Z, those born in the years 1995-2010. Teens Generation $\mathrm{Z}$ is also born and grew up at the time of the Internet is more developed than the previous generation. This leads to the generation of Internet literacy $Z$ has been since they were born. It is directly changed the ecological system in adolescents during the industrial revolution 4.0 this.

Education and the Internet, according to John Chamber, CEO of Cisco Systems Inc., [4] are two very influential equalizers in the last decade. With the internet, the behavior of people in work, study, play or socialize has changed. People prefer to interact through online media such as chat, social media, and blogs or microblogs such as Twitter, Instagram, Facebook, and others. Similarly, in learning, a term we often hear in learning with the Internet is e-learning, online learning, blended learning, hybrid learning, and others.

However, the problem is how to increase, and the equitable distribution of quality education, especially to the poor. The core of this problem is inequality still high achievements in the education sector. According to Hung and Makdissi [5] and Maipita et al, $[6,7]$ said poverty is still a crucial issue and a very complex phenomenon for each country. Even poverty alleviation has been a major goal of public policy in almost all industrialized countries [8]. The decline in poverty is the main goal of the fundamentals as indicators of the effectiveness of development programs [6,9]. This gap occurs in such things as the level of gender, that still happens gender gap in the distribution of education to stay (between rural and urban areas) as well as by the level of family poverty (between $20 \%$ and poorest $20 \%$ richest) Rahayu [10], Fahmi and Satriatna [11] states that the disparities of educational outcomes based on residence urban and rural areas show that urban people are always superior to the rural people. Joseph also said there are gaps in the net enrollment rate at the junior level for urban people is higher for the entire study period. While the gap between the net enrollment rate for urban and rural areas despite the university level has narrowed but still quite large. The condition of the average length of schooling of the population in urban and rural areas has not changed much.

The essence of all of the above problems is decrease to poverty. According to Maipita [12] explains that poverty has a broad impact on the lives, not only the private lives of the poor but also for people who are not considered poor. Poverty is not just a personal burden, but also a burden and a responsibility of society, country, and the world to mitigate them. Sharp et al., [13] A very powerful way that is believed to reduce poverty is through education. Empirical evidence suggests that increasing the poor's access to education, health, and reduce inequality in access will be essential for reducing poverty. Poverty can be caused by (a) the low quality of the labor force as a result of low levels of education,

The impressive improvement in human development in Indonesia which is indicated by the increase in education indicators Gross Enrollment Ratio (GER) for all levels of primary and secondary education as shown in Figure 1 below: 


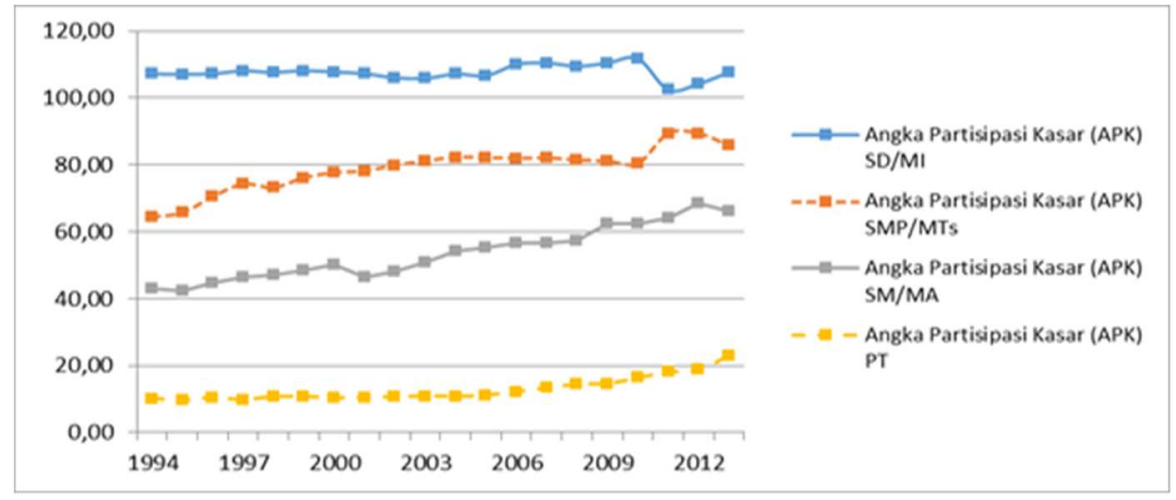

Source: Central Bureau of Statistics, processed.

Figure 1. GER Development in Indonesia School Year 1994-2013

The improvement in enrollment rates in Indonesia was not followed by an equal quality of education obtained every child. The provision of good quality education is the key to creating a quality generation. Inequality in education is still happening. The average length of schooling of the population only reached 7.9 years for females and 8.6 years for men. In the countryside, growing inequality sharply, men who do not go to school 5.3 percent and 11.9 percent of women [14].

Other important education indicators attained education level of population aged 15 years and over. A World Bank study in 2015 found that 71 percent of children from poor families are not likely to graduate from high school. While the rich kids only about 7 percent. The progress attained a population 15 years and over the period 1994 to 2013 as follows:

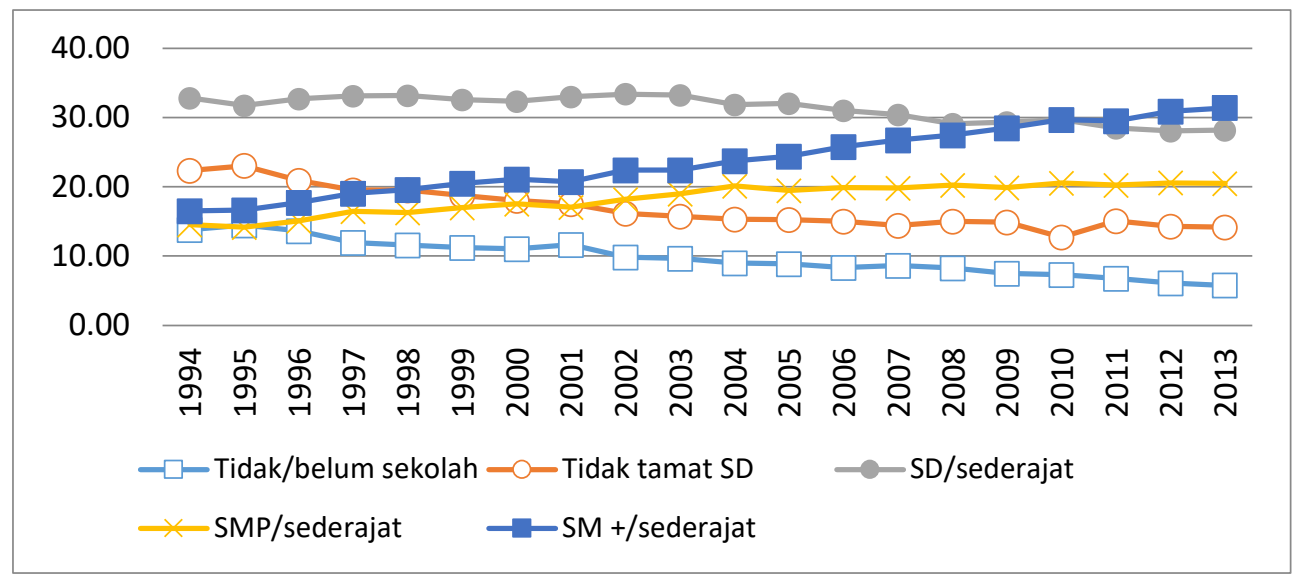

Source: Central Bureau of Statistics, processed.

Figure 2. Education Attainment Population 15 Years and Over Period 1994-2013

The figure above shows that the population aged 15 and over who have never attended school tends to decrease, as well as that, do not complete primary school, and only graduated from elementary school or equals. The decrease in all three categories is accompanied by an 
increasing number of people who graduated from junior and senior high school or the equivalent. Even from Figure 2 can be seen that the rising trend graph graduated from the high school population more sharply than those who just graduated from junior high school. This indicates that the increasing number of Indonesian people who have graduated from high school education.

Variables that affect the education of many submitted by various researchers. Variable income per capita, population growth rate, the level of government spending education sector, the total number of inhabitants and the total urbanization are the variables that have a significant influence on the educational level of adults in developing countries. On the other hand, Faguet and Sánchez [15] provide a more diverse variables to see the effect on education. The variables are spending per capita for the cost of public education, public expenditure on education, local government expenditure growth, the ratio of teachers to students, political, household demographics and socioeconomic status.

Based on the explanation above problems this study becomes very interesting when reviewing the inequality of education related to directly challenge the industrial revolution 4.0 where opportunities and threats must have faced in every transition of innovation and technology with the option capable of generating employment relevant to the development of technology or drowned by the era of disruption this.

\section{Research Method}

The model was based on primary literature referred from Rajkumar and Swaroop [16] and several other supporting articles such as Anyanwu [17]; Checchi [18]; Flug et al., [19]; Pritchett and Filmer [20] and Psacharopoulos [21].

This study looks at the poor educational inequality by factors suspected to affect is the per capita income, government spending, Gini coefficient, the population aged 0-14 years and 15-65 years of age. Models for educational inequality can be made by calculating the inequality index for the average length of the school with the following equation:

$$
I E Q_{-} R L S_{i t}=\gamma_{0}+\gamma_{1} P K_{i}+\gamma_{2} G O V_{-} E D_{i}+\gamma_{3} G I N I_{i}+\gamma_{4} A G E_{-} 014_{i}+\gamma_{5} A G E_{-} 1565_{i}+e_{i}
$$

Information:

$\begin{array}{lll}I E Q \_R L S & = & \text { On average Old School (The ratio is calculated as the Gini Index) } \\ P K & = & \text { Income per capita } \\ G O V E D & = & \text { Part of government expenditure (education sector GDP) } \\ \text { BOSS } & = & \text { School operational assistance } \\ \text { BOK } & = & \text { Health Operational Costs } \\ \text { GINI } & = & \text { Gini Index Ratio } \\ U M U R 014 & = & \text { residents in age } 0-14 \text { years } \\ U M U R 1565 & = & \text { residents in age 15-65 years } \\ \gamma, \rho & = & \text { the estimated coefficients } \\ i & = & \text { Province } \\ e_{i} & = & \text { variable disorder }\end{array}$

Fixed Effect use of models chosen because it can create a model specification for each variable based on cross-sectional data. This is to be able to provide a depth analysis of each province is in the model and make it easier to determine which province that has a greater impact have different roles based on coefficient signs. Data analysis techniques in this study using panel data regression with Eviews 10. 


\section{Results and Discussion}

Model inequality shows how several independent variables influencing predetermined gaps in the average length of the school. Inequality for each of these variables on educational indicators illustrates the distribution of the poor so that it can be measured the performance of the construction of the distribution of educational development of level.

Based on the results of hypothesis testing results are as follows:

Table 1. Fixed Effect Model Estimation Results for Educational Inequality

\begin{tabular}{lrrrr}
\hline & \multicolumn{1}{l}{ RLS } & standard Error & R2 & adj R2 \\
\hline constants & $\mathbf{1 . 5 8 8 2} * * *$ & -0403 & 0.5295 & 0.3896 \\
PK & $\mathbf{- 0 . 0 7 5 3} * * *$ & 0.0208 & & \\
GOV_EDit & $\mathbf{- 0 . 0 3 5 7} * * *$ & 0.0119 & & \\
GINIit & $\mathbf{0 . 5 4 9 8} * * *$ & 0.1124 & & \\
AGE_0-14it & $\mathbf{- 0 . 0 0 3 4} *$ & 0.0028 & & \\
AGE_15-65it & $\mathbf{0 . 0 0 2 9} * *$ & 0.0013 & & \\
\hline
\end{tabular}

Source: Research data, processed

Information:

- In brackets indicate the standard error

- * Indicates significance at the alpha level of $10 \%$

— $* *$ indicate significance at the alpha level of $5 \%$

- $* * *$ indicates significance at the alpha level of $1 \%$

Based on Table 1 above it can be concluded that the per capita income, government spending and the province of children 0-14 years of age a significant negative effect on the inequality of the average length of school. While the Gini ratio and the age of 15-65 years have a positive and significant impact on the inequality of the average length of the school.

Variable income per capita has a negative and significant impact on educational inequality average length of schooling of the population is poor. This is consistent with the hypothesis allegations. This means that if there is an increase in per capita income, the average level of inequality of the old school of the poor will tend to diminish. The results are consistent with research conducted by Komar 22], Rahayu [23], and Hamzah et al., [24] where the research he concluded that the higher the income per capita, the higher the success in the field of education. However, these studies are not consistent with that made by Widodo [25], in which the research conclusion states that the income per capita does not give effect to the education index measured by the literacy rate and the average length of the school. It also strengthens the opinion research Todaro \& Smith [26] said that when low-income people cannot borrow money, they are largely powerless to provide education for their children well or not be able to start or expand their businesses. This explains a relationship between education pursued by how much of the revenue earned. Educational inequities that occur can be caused by low-income communities in supporting themselves and their families. This explains a relationship between education pursued by how much of the revenue earned. Educational inequities that occur can be caused by low-income communities in supporting 
themselves and their families. This explains a relationship between education pursued by how much of the revenue earned. Educational inequities that occur can be caused by low-income communities in supporting themselves and their families.

Variable government spending has a negative and significant impact on educational inequality average length of schooling of the population is poor. This is consistent with the hypothesis allegations. This means that if there is an increase in government spending provinces, the average level of inequality of the poor old school in the province is likely to be reduced. This study is in line with Rahayu [10], Bustomi [27], and Hamzah et al., [24], but with a different research results Sholikhah, et al., [28] which states that government spending in education significant positive effect on inequality education in East Java province year period 2008 - 2012. Sholikhah, et al., [28] states that the allocation of investments which are not effective so that the amount of government spending in education today also enlarges the educational inequality counties and cities in the province of East Java. The results also reinforce the opinion Todaro \& Smith [1] said government intervention can be done is through the government's budget policies derived from income taxes by increasing poor people directly or indirectly, such as expanded access to basic education.

The variable provincial Gini ratio has a positive and significant effect on educational inequality average length of schooling of the population is poor. This is consistent with the hypothesis allegations. This means that if there is an increase in Gini provincial ratio, the average level of inequality of the poor old school in the province will increase. This reinforces the opinion of Todaro \& Smith [1] said that the high cost of quality education becomes a barrier for low-income families to finance the education of their children. Education portraits Indonesia (Central Bureau of Statistics, 2016) states that a person's level of education is still influenced by economic status. The higher a person's economic status, the higher the level of education to be graduated.

Variables provincial population aged 0-14 years had a negative and significant impact on educational inequality average length of the poor school at an alpha of $10 \%$. This means that if there is an increase in the number of people aged 0-14 years in each province, the average level of inequality old school in the province will tend to decline. As for the variable age of 15-65 years, the province's population has a positive and significant impact on educational inequality average length of schooling of the population is poor. This means that if there is an increase in the numbers of population aged 15-65 years in each province, the average level of inequality old school in the province will increase. A variable young age or 0-14 years of age do not have much effect even with a relatively small coefficient. This gives the notion that the presence of a young age could not determine the increase/decrease in educational inequality. Likewise, for adults, which does not have much effect with a relatively small coefficient.

Based on table above Per Capita Income in Sumatra has a negative sign the seven provinces of North Sumatra, West Sumatra, Riau, Jambi, Bengkulu, South Sumatra, and Lampung. While having a positive sign as many as two provinces of Aceh Province and Bangka Belitung. A positive coefficient sign explained that the increase in the average length inequality poor school when per capita income increases. While the negative coefficient sign is the decrease in the average length inequality school of the poor due to rising per capita income.

While the model specification of per capita income inequality variable Sumatra in the island can be seen from the following table: 
Table 2. Specifications Model Per Capita Income Inequality Variable Sumatra Island

\begin{tabular}{|c|c|c|}
\hline No. & Province & RLS \\
\hline 1 & Aceh & 0.24 \\
\hline 2 & North Sumatra & -0.75 \\
\hline 3 & West Sumatra & -0.18 \\
\hline 4 & Riau & -0.16 \\
\hline 5 & Jambi & -0.35 \\
\hline 6 & Bengkulu & -0.12 \\
\hline 7 & South Sumatra & -0.62 \\
\hline 8 & Bangka Belitung Islands & 0.14 \\
\hline 9 & Lampung & -1.9 \\
\hline
\end{tabular}

It is clear that from the 9 provinces in Sumatra island that observed in the study was a per capita income of Lampung province has the most impact on educational inequality decrease in the average length of schooling of the population is poor, followed for the next following are province North Sumatra and South Sumatra.

\section{Conclusion}

Income per capita, and the provincial government a significant negative effect on the inequality of the average length of the school. While the Gini ratio and the age of 15-65 years have a positive and significant impact on the inequality of the average length of the school. The small regression coefficient for the age group 0-14 years and 15-65 years of giving the notion that the presence of young age could not determine the increase/decrease of educational inequality. Likewise, for adults, which does not have much effect with a relatively small coefficient.

Government spending in education, the increase in per capita income, a decrease in income inequality into a powerful instrument for pressing educational inequality average length of schooling of the population is poor. If this effort is congested, then the threat of the low quality of human resources must have faced and generated employment which are not relevant to the development of technology or drowned out by the disruption of the era of today and for the future.

\section{References}

[1] Todaro, M.P, Smith, S.C, (2012), Economic development (the 11th edition). Boston: Pearson Addison Wesley.

[2] The World Bank. (1996), World Development Report: From Plant to Market. World Bank Publication.

[3] Hurlock, EB. (2002), Developmental Psychology ( $5^{\text {th }}$-ed). Jakarta : Erlangga.

[4] Kompasiana. (2019), 4.0 Effect of the Industrial Revolution in Education in Indonesia. https:/www.kompasiana.com/shahnazzhr/5cebf01295760e76fc2c3f34/pengaruhrevolusi-industri-4-0-dalam-pendidikan-di-indonesia. 
[5] Hung, Nguyen Manh and Paul Makdissi.(2004), Escaping the Poverty Trap in a Developing Rural Economy. The Canadian Journal of Economics / Revue Canadienne Economique, 37(1), pp.123-139.

[6] Maipita, Indra., Mohd. And male., And Nor Azam Abdul Razak, (2010), The Impact of fiscal policy toward Economic Performance and Poverty Rate in Indonesia. Bulletin Monetary Economics and Banking: Bank Indonesia, 12 (4), pp. 391-424.

[7] Maipita, I., Herman, W., Fitrawaty., Soecipto, EB. (2016), The Impact of Middle-Class Spending on Economic Growth and Industry in Indonesia. International Journal of Economic Research, IJER, 13 (3), pp. 813-828.

[8] Moller, Stephanie, Evelyne Huber, John D. Stephens, David Bradley, François Nielsen. (2003), Determinants of Relative Poverty in Advanced Capitalist Democracies. American Sociological Review, 68 (1), pp. 22-51.

[9] [Maipita, I., Hermawan, W, and Fitrawaty. (2012), Reducing Poverty Through Subsidies: Simulation of Fuel Subsidy Diversion to Non-Food Crops. Economics Bulletin of Monetary and Banking, Bank Indonesia, 14 (4), pp. 369-387.

[10] Rahayu, A. Education inequality in Indonesia. (2005), JESP, 6 (1), pp. 21-40.

[11] Fahmi, M., and Ben Satriatna. (2013), Development in Education Sector: Are the Poor Catching Up? Working Paper in the Center for Economics and Development Studies, Padjadjaran University, v.6.

[12] Maipita, Indra. (2014), Measuring Poverty and Income Distribution. Yogyakarta: UPP STIM YKPN.

[13] Sharp, AM, Register, CA, Grimes, PW. (2000), The Economics of Social Issues, (14thEd), New York: Irwin / McGraw-Hill.

[14] Tempo. (2016), Kartini and Education Inequality Perempuan. News Coverage, Tempo, edition of 21 April 2016.

[15] Faguet, Jean-Paul, and Fabio Sánchez. (2008), Decentralization's Effects on Educational Outcomes in Bolivia and Colombia. World Development, 36 (7), pp.1294-1316.

[16] Rajkumar, Andrew Sunil, and Vinaya Swaroop. (2008), Public Spending and Outcomes: Does Governance Matter? Journal of Development Economics, 86 (1), pp. 96-111.

[17] Anyanwu, JC., And Erhijakpor. (2007), AEO. Education Expenditures and School Enrollment in Africa: Illustrations from Nigeria and Other SANE Research Countries. Economic Working Paper, no. 92.

[18] Checchi, Daniele. (2014), Inequality in incomes and Access to Education: A CrossCountry Analysis. Retrieved on https://air.unimi.it/retrieve/handle/ m2434/15297/85963 / Inequality in incomes and Access.pdf.

[19] Flug, Karnit, Antonio Spilimbergo, and Erik Wachtenheim. (1998), Investment in Education: Do Economic Volatility and Credit Constraints Matter? Journal of Development Economics, 55 (2), pp. 465-81.

[20] Pritchett, Lant, and Deon Filmer. (1999), What Education Production Functions Really Show: A Positive Theory of Education Expenditures. Economics of Education Review, 18, pp. 223-39.

[21] Psacharopoulos, George. (1994), Returns to Investment in Education: A Global Update. World Development, 22 (9). 
[22] Komar, O. (2004), The linkage with the Population Quality Education Problem. Padjadjaran Population Journal, pp. 87-94.

[23] Rahayu, Astuti. (2010), Gender Gap in Education Distribution in Yogyakarta. Economic Bulletin, 8 (1), pp. 49-58.

[24] Hamzah, F, et al. (2017), Influence of Government Expenditure for Education, Gender Gap, and Income Per Capita Against Education and Inequality in Income Inequality Regency / City in the province of West Kalimantan. Journal of Business Economics and Entrepreneurship, 6 (2), pp. 77-96

[25] Widodo. (2013), Effect of Per Capita Income, Expenditure Education And Against Dependency Ratio Index Musi Rawas Education in South Sumatra Province. Bengkulu: Bengkulu University.

[26] Todaro, MP, \& Smith, SC. (2011), Economic Development (11 ${ }^{\text {th }}$-Ed), I. Jakarta: Erland.

[27] Bustomi, MJ. (2012), Education Inequality Inter-District / City and Its Implications in Central Java province. Analysis Development Economics Journal, pp. 1-10.

[28] Sholikhah, N., Suratman, B., Soesatyo, Y., \& Soejoto, A. (2014), Analysis of Factors Affecting Education Inequality. Journal of Science Education, 20, pp. 176-182. 